\title{
Iumatti, Paulo Teixeira História, Dialética e Diálogo com as Ciências: a gênese de Formação do Brasil Contemporâneo, de Caio Prado Jr. (1933-1942)
}

\author{
Leonardo Octavio Belinelli de Brito*
}

São Paulo: Intemeios, 2018. 538 p.

Como produzir uma grande obra de pensamento em um contexto periférico? É com essa pergunta que Paulo Teixeira Iumatti abre o seu História, dialética e diálogo com as ciências: a gênese de Formação do Brasil contemporâneo, de Caio Prado Jr. (1933-1942), livro originado de sua tese de doutorado, produzida no âmbito do Programa de Pós-Graduação em História Social da Universidade de São Paulo (USP) e concluída em 2001. De saída, cabe destacar a potência que o qualificativo "contexto periférico" dá à pergunta, pois afasta dela o idealismo próprio às posições que frisam o talento superior do indivíduo ou àquelas que acreditam numa espécie de circulação mundial igualitária de ideias. Já aqui a dimensão materialista, tão ao gosto do seu objeto, aparece com discreta precisão.

Perseguindo sua indagação inicial, Iumatti apresenta uma pesquisa alentada. Embora partes dela já houvessem aparecido em outras publicações, inclusive na forma de livro (Iumatti, 2007), a exposição da pesquisa completa revela um fôlego que talvez não se dimensione com facilidade e que requer do leitor certa paciência com a busca incessante pela comprovação, o que, se por um lado pode comprometer o prazer da leitura, é, por outro, próprio à verificação científica.

Se situada historicamente, a pesquisa de Iumatti ganha um interesse não evidente. A partir dos anos 1990, surgiram trabalhos muito competentes sobre Caio Prado Júnior, entre os quais podemos destacar os de Bernardo Ricupero $(2000)^{1}$ e Paulo Henrique Martinez (2008); ${ }^{2}$ na década seguinte, foi a vez de Lincoln Secco (2008). Na atual, Luiz Bernardo Pericás (2016) publicou uma

\footnotetext{
* Doutorando, Universidade de São Paulo (USP), Programa de Pós-Graduação em Ciência Política, São Paulo, SP, Brasil. belinelli.leonardo@gmail.com <https://orcid.org/0000-0002-4622-5366>
} 
biografia política de Prado Júnior, aliás já comentada por Iumatti (2016). Cada um a seu modo, todos chamam a atenção para a dimensão criativa do pensamento de Caio Prado Júnior, caracterizado por Iumatti como "experimental, inquieto e iconoclasta" (p. 19, grifo no original). Embora não convenha a este texto, dadas as restrições que cabem a uma resenha, seria o caso de ler tal bibliografia em conjunto e de modo comparado, tendo em mente os motivos pelos quais Prado Júnior passou a ser resgatado por pesquisadores justamente em um momento no qual o marxismo estava "em baixa e passa[va] por ser uma ladainha” (Schwarz, 2014, p. 104). É razoável supor que a criatividade de Caio Prado Júnior fosse um dos motivos de tal resgate. Seja como for, vamos nos limitar a chamar a atenção para a forma com a qual Iumatti segue essa percepção e alguns de seus desdobramentos, pois é ela que articula os planos que conferem originalidade à sua pesquisa.

A pista inicial é revelada logo no subtítulo do livro: em pesquisa muito detalhada e rigorosa, repleta de dados pouco conhecidos, Iumatti persegue o processo que deu origem ao livro mais importante de Caio Prado Júnior, Formação do Brasil contemporâneo (1942), tendo em vista "compreendê-lo em seus próprios termos" (p. 20, grifo no original).

Os resultados da pesquisa são apresentados de acordo com uma forma que não tem nada de casual. O livro começa com um capítulo no qual são investigadas as condições que propiciaram o surto modernizante na cidade de São Paulo entre os anos 1930-1940 (capítulo 1) e termina com uma discussão sobre o problema do tempo no pensamento de Caio Prado Júnior (capítulo 7). Entre esses capítulos, há aqueles nos quais são investigados a importância de Formação do Brasil contemporâneo na historiografia brasileira e internacional (capítulo 2); os primeiros livros de Caio Prado Júnior e sua atuação na Faculdade de Direito (capítulo 3), marcados pelo evolucionismo marxista; os seus estudos de Geografia, Antropologia e Sociologia (capítulos 4 e 5), e aquele no qual se investigam a forma e o método de Prado Júnior na escrita de seu principal clássico (capítulo 6). Vista assim, percebe-se que a estrutura do livro parece conduzir ao estudo da introjeção das injunções externas à própria forma do livro. Ou seja: passamos das linhas históricas gerais (e no plano explicativo, mais abstratas) ao plano das particularidades - isto é, o modo pelo qual Prado Júnior incorporou em seu trabalho as circunstâncias vividas pessoal e coletivamente.

Nesse caso, na argumentação de Iumatti é decisivo o sentido modernizante das práticas historiográficas de Caio Prado Júnior. Orientadas desse modo, elas se aliavam aos acontecimentos de sua época, como atesta a criação de 
universidades (especialmente a da Universidade de São Paulo) e instituições culturais, e mesmo um forte adensamento do mercado editorial. Além disso, teriam contado para a renovação do ambiente intelectual os desdobramentos éticos e estéticos do modernismo. Exemplo disso é a disseminação, iniciada nos anos 1920, de reflexões sobre questões referentes à integração social dos excluídos, as quais alimentaram nossa literatura e nosso pensamento social. No que se refere ao último, passava-se a prestar atenção aos impasses da população rural, tema de pesquisas e interpretações desenvolvidas entre os anos 1930 e 1940. Eis um dos pontos altos do livro, na medida em que a análise de Iumatti logra demonstrar como uma questão socialmente disseminada se converteu em tema de pesquisa de Prado Júnior, que a combinou com as discussões teórico-metodológicas feitas na USP e na Associação dos Geógrafos Brasileiros. Ou seja: como questões externas se convertem em dínamo interno de Formação do Brasil contemporâneo.

No que se refere à escrita da obra, Iumatti demonstra, por meio do cotejamento entre relatos de viagens de Prado Júnior e passagens de seu livro, a forma como o autor vinculava seus estudos às suas viagens, momentos nos quais colocava em prática a teoria aprendida em suas leituras de História e Geografia. Uma forma que, se por um lado, destaca a dimensão pessoal do pesquisador, por outro relativiza-a, pois frisa a importância do conhecimento sobre as perspectivas dos objetos acerca dos quais escreve. Digamos que se trata de uma dialética peculiar, própria à prática científica que busca o concreto.

Notando a complexificação que Caio Prado Júnior empresta ao problema das temporalidades no decorrer de sua obra, Iumatti encerra seu livro tratando da relação desse autor com Fernand Braudel e da forma como o historiador paulista trata a questão do tempo em Formação do Brasil contemporâneo. Esta, aliás, parece ser uma das boas sugestões da obra: entender a evolução intelectual de Prado Júnior a partir do problema do tempo em seu pensamento, tema que constitui um dos prismas pelos quais se pode averiguar a densidade de uma reflexão historiográfica. Agregue-se a isso a importância que a questão assume em um país periférico, ele mesmo costumeiramente regido por determinações desiguais e combinadas; o resultado será uma conjugação que repõe a pergunta com a qual Iumatti começou sua obra.

Tendo tudo isso em vista, o livro de Iumatti é uma aquisição importante ao debate brasileiro sobre a história intelectual do país, com destaque para as áreas de história da historiografia e pensamento político e social brasileiro. Preocupado com a dimensão epistemológica do trabalho de Caio Prado Júnior, talvez se possa indicar que faltou ao livro destacar seu engajamento político, 
sem o qual ela parece abstrata. É bem verdade que talvez isso se deva ao fato de que o engajamento de Prado Júnior é um dos elementos mais destacados de sua personalidade, o qual, frequentemente, torna secundária a dimensão teórico-historiográfica de seu pensamento, elemento caro ao trabalho de Iumatti. Sorte a do leitor, que ganha com trabalhos ricos e com perspectivas diferentes.

\section{REFERENNCIAS}

IUMATTI, Paulo Teixeira. A biografia política de Caio Prado Jr. (Resenha). Revista Pesquisa Fapesp, São Paulo, n. 247, set. 2016. Disponível em: http://revistapesquisa. fapesp.br/2016/09/23/a-biografia-politica-de-caio-prado-jr/.

IUMATTI, Paulo Teixeira. Caio Prado Jr.: uma trajetória intelectual. São Paulo: Brasiliense, 2007.

MARTINEZ, Paulo Henrique. A dinâmica de um pensamento crítico: Caio Prado Jr. (1928-1935). São Paulo: Edusp, 2008.

PERICÁS, Luiz Bernardo. Caio Prado Júnior: uma biografia política. São Paulo: Boitempo, 2016.

RICUPERO, Bernardo. Caio Prado Jr. e a nacionalização do marxismo no Brasil. São Paulo: Ed. 34 : Departamento de Ciência Política/USP : Fapesp, 2000.

SCHWARZ, Roberto. Sequências brasileiras. 2. ed. São Paulo: Companhia das Letras, 2014.

SECCO, Lincoln. Caio Prado Júnior: o Sentido da Revolução. São Paulo: Boitempo, 2008.

\section{NOTAS}

${ }^{1}$ Originado de um mestrado defendido em 1997 no Departamento de Ciência Política da Universidade de São Paulo (USP).

${ }^{2}$ Originado de doutorado defendido em 1999 no Departamento de História da Universidade de São Paulo (USP).

Resenha recebida em 5 de julho de 2018.

Aprovada em 13 de setembro de 2018. 